\title{
Shaping Digital Innovation Via Digital-related Capabilities
}

\author{
Mina Nasiri $^{1}$ (D) $\cdot$ Minna Saunila $^{1} \cdot$ Juhani Ukko $^{1} \cdot$ Tero Rantala $^{1} \cdot$ Hannu Rantanen ${ }^{1}$
}

Accepted: 3 November 2020

(C) The Author(s) 2020

\begin{abstract}
The aim of this research was to explore the conditions under which digital innovation opportunities emerge in small and mediumsized enterprises (SMEs). The research answered the question of what capabilities are required to shape the exploitation of digital innovation, namely market offerings and the digital business process. To address the research question with a quantitative research method, data were collected through survey questionnaires distributed among 280 SMEs operating in the service and manufacturing industries in Finland. The results revealed that among four digital-related capabilities - namely human, collaboration, technical, and innovation capabilities — human, technical, and innovation capabilities contribute to market offerings, while human, collaboration, and technical capabilities contribute to the business process.
\end{abstract}

Keywords Digital innovation $\cdot$ Digital-related capabilities $\cdot$ Digital transformation $\cdot$ Market offerings $\cdot$ Digital business process

\section{Introduction}

As digital transformation is shaping the business environments of contemporary companies, companies need the adjust their operations and find ways to respond to the changes. To operate in increasingly digitalized business environments, and as a part of the digital ecosystems (Delgosha et al. 2020; Pappas et al. 2018), companies need to not only find innovations and innovative ways to change their businesses but also develop capabilities to exploit innovation in changing surroundings. Further, Mikalef et al. (2020), argued that to derive value from the growing opportunities of digitalization, such as big data, companies need to develop the organizational capacity to recognize how their businesses can benefit from data-

\section{Mina Nasiri}

mina.nasiri@lut.fi

Minna Saunila

minna.saunila@lut.fi

Juhani Ukko

juhani.ukko@lut.fi

Tero Rantala

tero.rantala@lut.fi

Hannu Rantanen

hannu.rantanen@lut.fi

1 School of Engineering Science, Department of Industrial Engineering and Management, LUT University, Mukkulankatu 19, 15210 Lahti, Finland driven insight, as well as develop capabilities to implement these recognized possibilities. In other words, companies need to find ways to exploit digital innovation. Therefore, the dominant role of digital innovation is being increasingly observed in the business environment due to new opportunities that offer firms the potential to broaden into new and special experiences (Jahanmir and Cavadas 2018; Kolloch and Dellermann 2018; Nylén and Holmström 2015), leading to high profit potential and customer satisfaction (Bednar and Welch 2019; Parida et al. 2015). The origins of digital innovation can be traced to digitalization (Chan et al. 2019), which acts as an enabler of and creates essential conditions for exploiting digital innovation (Yoo et al. 2010). Such exploitation requires capabilities, relevant to digitalization, that respond appropriately to market opportunities and digital transitions. Further, in responding to digital transitions, alignments between organizational capabilities and market demands must be created, as misalignments in this dynamic can lead to business failure (Chan et al. 2019).

Pappas et al. (2018) argued that to reach digital transformation and the creation of sustainable societies, none of the operators in society should be seen in isolation; instead, there is a need to improve the understanding of how their interactions lead to knowledge, innovation, and value creation. Digitalization provides many ideal opportunities, particularly for small- and medium-sized enterprises (SMEs), and the interplay between companies' different types of capabilities and innovation in digitalizing business is of growing interest to both academics and practitioners (Bednar and Welch 2019; Mikalef et al. 2018). For example, Mikalef et al. (2019) 
examined the indirect relationship between a Big Data analytics capability and two types of innovation capabilitiesincremental and radical. As a part of the companies' innovation activities in digitalizing business environments, such as those related to Big Data analytics or business ecosystem activities, it is important to develop theory and conduct practical research that will incorporate the phenomenon called digital innovation (Nambisan et al. 2017). In the big picture, digital transformation requires companies of all sizes to rethink and innovate their businesses, yet SMEs may have little time and few resources for experimenting with their businesses or for implementing new strategies (Bouwman et al. 2019). Recent research has investigated how SMEs with inadequate capabilities and limited resources drive digital transformation ( $\mathrm{Li}$ et al. 2018) and has further demonstrated the lack of understanding of the capabilities of SMEs with respect to different aspects of digital transformation. As such, the topic has gained interest among academics. For example, Cenamor et al. (2019) examined the effect of digital platform capability and network capability on the financial performance of entrepreneurial SMEs, while Neirotti et al. (2018) explored how SMEs develop ICT-based capabilities in response to their environment. Overall, few studies have concentrated on the firm-level capabilities needed for digital innovation (Kohli and Melville 2019). This study sheds light on exploiting digital innovation by identifying the required capabilities in digital transformation and understanding the way of utilizing those capabilities. In this study, digital-related capabilities were defined as organizational capabilities in terms of multidimensional constructs, such as human (Chan et al. 2019; El Sawy et al. 2016; Kane et al. 2015; Legner et al. 2017), collaboration (Amit and Han 2017; Chuang and Lin 2015; El Sawy et al. 2016; Pagani and Pardo 2017; Sjödin et al. 2016), technical (El Sawy et al. 2016; Parida et al. 2015; Sjödin et al. 2016; Yoo et al. 2010), and innovation (Parida et al. 2015; Sjödin et al. 2016; Sousa and Rocha 2019; Xue 2014) capabilities. These capabilities enable companies to respond quickly to digital transformation and to thereby exploit digital innovation (Fichman et al. 2014; Kohli and Mekville 2019; Nambisan et al. 2017; Nylén and Holmström 2015; Urueña et al. 2016). Successful digital innovation greatly depends on how capabilities are understood and, subsequently, how such capabilities are adapted with regard to innovation outcomes, processes, and related markets (Nambisan et al. 2017; Nylén and Holmström 2015). Moreover, digital innovation is incorporated into the continuous matching of digital-related capabilities with traditional market offerings (Nambisan et al. 2017).

However, research on the types of capabilities required to shape the evolution of the digital innovation phenomenon is lacking. This is referred to as the process perspective on digital innovation, and it includes the actions and outcomes of digital innovation (Kohli and Melville 2019). Traditionally, the main focus of innovation management research has been on either innovation development actions or innovation outcomes (i.e., Ahmad et al. 2013; Sivasubramaniam et al. 2012). Digital innovation involves both actions and outcomes, as suggested previously (i.e., Lee and Berente 2012; Nambisan et al. 2017). Few studies have concentrated on the firm-level capabilities needed to identify, assimilate, and apply valuable knowledge from both inside and outside the firm with regard to opportunities for digital innovation, known as initiate activity (Kohli and Melville 2019). Therefore, the scope of this study was formed on the following basis: innovation is considered to cover both the digital-related capabilities that comprise the basis of the initiate activity and digital innovation as an outcome.

To address the abovementioned research gap, this study utilizes a quantitative research method. The aim of the study is to explore the conditions under which digital innovation opportunities emerge in SMEs. The following research question was addressed: What capabilities are required to shape the exploitation of digital innovation? To answer this research question, a structured survey questionnaire was administered to 280 SMEs operating in the service and manufacturing industries in Finland. First, this research contributes to the process perspective of digital innovation, considering digital innovation as an outcome and the capabilities needed to create it. Further, by incorporating the effects of digital-related capabilities based on the digital innovation type, the research extends the digital innovation literature. The research focused on SMEs because, despite the perception that SMEs are frequently hampered by a lack of resources and capabilities, the probability of successfully exploiting digital innovation was higher for SMEs than it was for large and well-established companies (Street et al. 2017). This may be because SMEs have the capability to move quickly and easily, whereas large companies are frequently unwilling to adopt digital innovations because of the risk of losing their current competitive advantages. Moreover, organizations that are mature and welldeveloped are marked by institutionalized processes, capabilities, and cultures that, in this case, may hinder their ability to respond to digital transitions (Chan et al. 2019).

The rest of the paper is structured as follows. Next, the theoretical framework for the study, including its theoretical underpinnings and key concepts, is presented. After this, the research model used in the study is described, including a discussion of the research hypotheses. Afterward, the research methodology is presented, followed by a discussion of the research results. Lastly, the conclusions of the study are summarized. 


\section{Theoretical Framework}

\subsection{Dynamic Capabilities and Digital Innovation}

Innovation is the creation and adoption of a practice or object considered novel (Rogers 1983). Creating innovation is achieved through distinct resources. Resources can be either tangible, such as humans and technology, or intangible, such as knowledge (Davila et al. 2012). These resources ensure the efficient execution of innovative routines within firms. As one of the driving forces of innovation creation, digital transformation not only provides novel opportunities for companies but also necessitates an understanding of what capabilities are required and how those capabilities should be adapted with regard to innovation outcomes, processes, and related markets (Kohli and Melvill 2019; Nambisan et al. 2017). Current research has stated that firms use dynamic capabilities to adapt, integrate, or reconfigure existing resources and skills to readjust to environmental change (Teece et al. 1997). The dynamic capabilities theory deals with the unique, difficult-to-replicate capabilities that allow rapid adaptability to changes in the external environment (Teece 2014; Teece et al. 1997). Thus, this theory is well-suited to examine changes caused by digital transformation. Dynamic capabilities reside in "interrelated routines within firms for performing specific tasks" (Ngo and O'Cass 2013, p. 1135). To classify exisiting capabilities, research on the routines and operations used by firms for developing digital innovation is needed. Thus, the following sections review the characteristics of digital innovation as well as the related capabilities presented in prior research.

Digital innovation has radically altered the structure of new products, services, and business processes, leading to novel value creation and competitive advantages for companies (Fichman et al. 2014; Nambisan et al. 2017). Greater exploitation of digital innovation requires bundles of new and complementary capabilities (Fichman et al. 2014; Lusch and Nambisan 2015; Nambisan et al. 2017; Nylén and Holmström 2015). Digital innovation can be explained as the creation of market offerings and business processes as an outcome of using digital technologies (Nambisan et al. 2017). Consequently, the definition of digital innovation includes two noteworthy and concurrent phenomena-namely, products/services and business processes (i.e., the way of doing things in an organizational setting) - both of which are enabled by digitalization (Fichman et al. 2014; Nambisan et al. 2017; Nylén and Holmström 2015).

\subsection{Digital-related Capabilities}

In the current digital era, digitalization is blurring all industry boundaries, and yet fixed and bounded strategies continue to be applied, consequently limiting the full exploitation of digital innovations. Thus, it is necessary to develop strategies and capabilities based on dynamic and fluid perspectives (Lyytinen et al. 2016; Yoo et al. 2010). This means that capabilities once considered practical may now be impractical or even damaging for the new, emerging condition (Chan et al. 2019). As a result, there are demands for developed and combined capabilities that will permit companies to offer modern service offerings. These combined capabilities include service development capabilities (i.e., developing new offerings and solutions), network management capabilities (i.e., knowledge sharing with the right partners), and digitalization capabilities in terms of technical abilities (i.e., integrated and smart systems), which play a key role in the provision of advanced market offerings (El-Haddadeh 2020; Sjödin et al. 2016). Thus, in this study, digital-related capabilities were defined as organizational capabilities in terms of multidimensional constructs, such as human, collaboration, technical, and innovation capabilities, for moving toward digitalization. These digital-related capabilities help companies to respond quickly to digital transformation and to exploit digital innovations (Kohli and Mekville 2019; Sjödin et al. 2016; Urueña et al. 2016).

Referring to human capabilities, as the source of digital innovation, digitalization requires employee support, readiness, and digital know-how (Chan et al. 2019; El Sawy et al. 2016; Kane et al. 2015; Legner et al. 2017). Companies that lack digitally skilled employees and/or staff skilled at problem solving suffer from deficient capabilities because of the complexity typifying the current digital era (Kache and Seuring 2017; Lerch and Gotsch 2015). Thus, in this study, digitalrelated human capabilities can be defined as the set of capabilities, knowledge, and skills that employees need in order to move toward digitalization.

Because of the complex nature of digitalization, achieving competitive advantages through single actors is not possible (Canhoto et al. 2016; Kohli and Mekville 2019; Pagani and Pardo 2017). Therefore, it is necessary to acquire collaboration capabilities in order to sustain a viable alliance and build value networks with the right partners (Amit and Han 2017; El Sawy et al. 2016; Pagani and Pardo 2017; Sjödin et al. 2016). Since digitalization has changed the structure of social relationships, in both internal and external company spaces (Pagani and Pardo 2017), SMEs must seek opportunities for collaborating with partners, thereby complementing their current capabilities with partners' capabilities (Chan et al. 2019). Collaboration capabilities enable learning via the exchange and sharing of knowledge and experience through digital channels, which are facilitated by digitalization (Chuang and Lin 2015; Legner et al. 2017; Maravilhas and Martins 2019). Therefore, in this study, digital-related collaboration capabilities are among the capabilities necessary to move toward digitalization.

In the current digital era, the utilization of both internal and external organizational cooperation requires technical 
capabilities as a complementary channel for ensuring the provision of advance market offerings (Legner et al. 2017; Sjödin et al. 2016). Thus, these capabilities play a critical role in the use of digitalization for integrating products and services (El Sawy et al. 2016) and for accessing updated and borderless services and activities (Parida et al. 2015; Sjödin et al. 2016; Yoo et al. 2010). Hence, in this study, digital-related technical capabilities refer to the bundle of technical capabilities that facilitate the implementation of digitalization in companies.

Disruptive digital business, which emerges from digitalization, requires innovation capabilities to be managed successfully (Sousa and Rocha 2019). The capacities to innovate, identify, and exploit business opportunities, as well as to diversify the business area, are among the innovation skills needed for disruptive digital business (Sousa and Rocha 2019). Moreover, the ability to develop new ideas, solutions, and novel offerings are among the most important capabilities for companies to possess in the current digital era (Parida et al. 2015; Sjödin et al. 2016; Xue 2014). Thus, digital-related innovation capabilities are required for companies to advance toward digitalization.

In sum, in responding to the exploitation of digital innovation, organizations frequently require development capabilities, which correspond closely to new situations and dynamic changes. In addition, organizations simultaneously require the mitigation of inflexibility in order to better equip themselves in the face of transformations (Chan et al. 2019; Kohli and Melville 2019; Parida et al. 2015; Sjödin et al. 2016). Thus, with regard to digital-related capabilities, human, collaboration, technical, and innovation capabilities are all recommended for companies to increase their odds of survival in the current competitive environment.

\section{Research Model and Hypothesis Development}

\subsection{Research Model}

This study aimed to explore the conditions under which digital innovation opportunities emerge in SMEs. Further, this research sought to contribute to the process perspective of digital innovation, considering digital innovation as an outcome and the capabilities needed to create it. Figure 1 depicts the proposed research model, which postulates a number of direct linkages between digital-related capabilities (namely human, collaboration, technical, and innovation capabilities) and digital innovation (namely market offerings and the business process).

To better understand the effects of digital-related capabilities on the exploitation of digital innovation, specifically in market offerings and business processes, eight direct hypotheses were developed and will be discussed in the following section. In addition, to understand the mechanisms behind the eight direct hypotheses, this paper examined whether digital-related capabilities indirectly affect digital innovation. This analysis provides a basis for further research related to hypothesizing and testing mediation and moderation effects.

\subsection{Hypotheses}

\subsubsection{Effects of Digital-related Capabilities on Market Offerings}

Digital transformation in companies and contemporary digital solutions can reduce the development time needed for generating innovations and launching them on the market (Marion et al. 2015). As such, most recent digital solutions and digital technologies have been integrated into companies' product and service development, thereby affecting their market offerings (Nylen and Holmström 2015; Yoo et al. 2012). Although digital transformation provides possibilities for automatizing products and making services smarter, human senses and capabilities still form an important part of successful digital innovation. Nylen and Holmström (2015) argued that digital services and solutions must not only be efficient to learn and easy to use but must also consider user experience. To comprehend the usability and user experience of digital innovation, companies must understand their customers' needs as well as the possibilities entailed by the utilization of developed products and services. The gathering of feedback and the understanding of customers' needs require human senses and digital-related human capabilities. Hoe (2017) claimed that the main argument for these thinking skills in digital business environments is putting end users' and customers' wishes and needs first and developing digital innovations to fulfill them. In other words, employees need to understand the interplay between the possibilities created by digital transformation and the wishes of digital innovation users.

According to Porter and Heppelmann (2015), making products and services smarter widens opportunities for companies' capabilities to, for example, monitor products and services and personalize product functioning. Human capabilities are needed to integrate organizations' core competitive advantages and knowledge with these widened opportunities to generate successful digital innovations that can leverage market offerings. As Fuchs and Sevignani (2013) suggested, the creation of new products in the digital work context also requires human brains and human experiences. According to Nylen and Holmströn (2015), the realization of digital innovation requires new skills, and companies must develop their mechanisms for supporting the advancement of digital-related human capabilities and continuous learning in digitalizing operating environments. As such, companies must ensure that 
Fig. 1 Research model and hypotheses

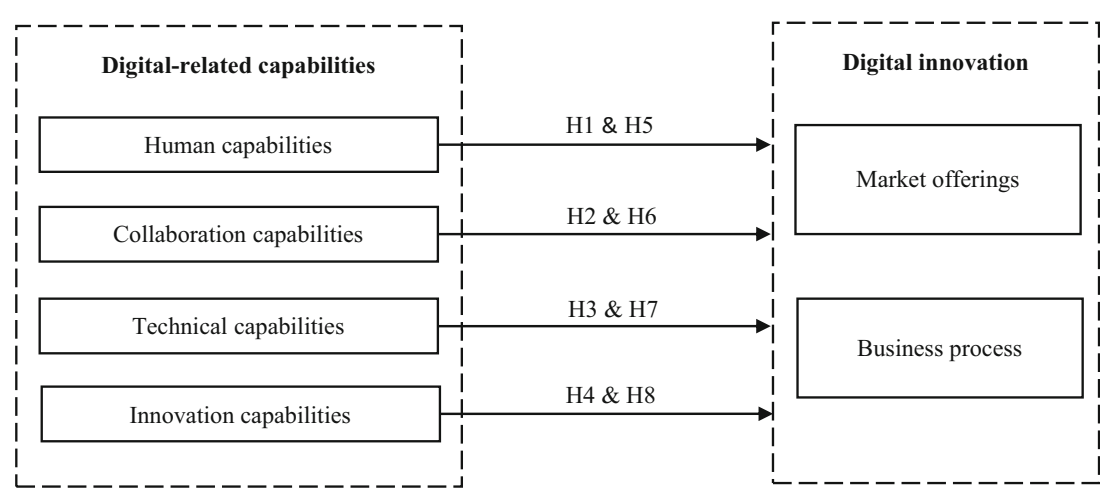

their employees are trained in the use and acceptance of digital solutions. Based on these arguments, the following hypothesis was proposed:

H1: Human capabilities relate positively to digital market offerings.

The idea of creating innovative products and services via collaboration has gained significant scholarly attention and has become the main focus of many companies (Luo et al. 2010; Santoro et al. 2018). For instance, a joint venture between IBM, Sony, and Toshiba facilitated the development of advanced chips for consumer electronics, culminating in a cell processor that supplied power for Sony's PlayStation 3 video game console. Masashi Muromachi, chief executive officer (CEO) of Toshiba, called this "a winning combination" (Luo et al. 2010, p. 245). Furthermore, many different researchers have considered collaborative activities as a way to stimulate digital innovation (Fichman et al. 2014; Maravilhas and Martins 2019). Fichman and colleagues (2014) used the term "network effects" as a label for capturing the tendencies of digital innovation and for addressing the relative ability to communicate or share digital assets among users. Furthermore, Lyytinen and colleagues (2016) referred to networks as a catalyst for the faster expansion of digital product innovation via borderless access to digital tools. In their research, they mentioned that, in the current digital era, there is a need for networks to collect knowledge flows around new products and services alongside digital tools for the further development of these products and services in order to successfully pursue radical innovations (Lyytinen et al. 2016). Hence, product innovation can be achieved via both internal development activities and external collaboration (Hull and Covin 2010; Luo et al. 2010; Lyytinen et al. 2016).

Because of the complex nature of market offerings in the digital era, providing successful market offerings with a single actor does not work (Canhoto et al. 2016; Kohli and Mekville 2019; Lyytinen et al. 2016; Pagani and Pardo 2017). Therefore, adopting collaboration perspective has been mentioned as a practical option for companies involved with digitalized supply chains (Pagani and
Pardo 2017; Peppard and Rylander 2006). According to Maravilhas and Martins (2019), the exchange and sharing of knowledge, information, and experiences among users via digital channels stimulate innovation, and this is called collaborative innovation. Digital channels provide an opportunity for aggregating product demands, resulting in an increase in the diversity of the developed market as well as more diverse product and service offerings (Brynjolfsson et al. 2010). Moreover, shaping the nature of digital innovation as collective actions requires different collaboration capabilities among partners, which are enabled by digitalization (Lyytinen et al. 2016; Nambisan et al. 2017; Yoo et al. 2012). Therefore, building on the literature discussed above, the following hypothesis was proposed:

$\mathrm{H} 2$ : Collaboration capabilities relate positively to digital market offerings.

Technical capabilities are presented as main enablers of organizational capabilities toward digital innovation (Banker et al. 2006; Mithas et al. 2011; Setia et al. 2013; Tanriverdi 2005) because digital technology creates a bond between the physical and digital characteristics of products and services (El Sawy et al. 2016). At present, digital technology is more affordable and ubiquitous than ever before, which has in turn facilitated more engagement with digital innovation, thereby allowing new configurations of actors to develop, generate, and invest in new digital products and services (Nylén and Holmström 2015; Yoo et al. 2010). Digital technology has made it technically possible to upgrade the functionality of products and services due to the reprogrammable nature of these capabilities. Thus, the technical capabilities concerning digital technologies are related to value propositions of digital products and services, addressing how value is generated and captured in each digital product and service (Nylén and Holmström 2015).

The technical capabilities of digitalization has permitted activities to cross the boundaries of time, place, and function (Parida et al. 2015; Yoo 2010; Yoo et al. 2012; Nylén and Holmström 2015) demonstrated that digital 
technology provides the potential for a reinvention of sales and distribution channels. Furthermore, they noted that firms are now able to carefully place and integrate their products and services with an abundance of mobile operating systems, social media sites, and app stores. In sum, this paper suggests that by keeping up to date with technical capabilities (e.g., analyzing the progress of digital technology and associated usage patterns; Nylén and Holmström 2015), firms can develop their digital market offerings in terms of novel digital products and services. In line with the considerations above, the following hypothesis was proposed:

H3: Technical capabilities relate positively to digital market offerings.

Advancing innovation potential among companies is crucial for digital innovation (Sia et al. 2016; Sousa and Rocha 2019) studied digital innovation in terms of disruptive technological phenomena, such as mobile technologies, artificial intelligence, big data, and robotics, and they found that the exploitation of such phenomena requires various innovation skills. These skills include the capability for creativity, the recognition of novel business openings, and the arrangement of indispensable resources corresponding to these openings. Similarly, Fichman et al. (2014) stated that digital innovation requires an understanding of what has become possible due to advances in technology, as well as the exploitation of this understanding to create something valuable for the company or for society. The development of digital innovation also depends on the relative capability to balance between present and necessary capabilities (Svahn et al. 2017). Nylen and Holmström (2015) believed that this was due to the unique features of the processes related to digital innovation. They also suggested that companies should question their existing product and service portfolios, digital surroundings, and traits used to promote digital innovation. Exploiting novel opportunities for innovation is key to generating a compiled value by creating digital products and services (Nylen and Holmström 2015), thereby casting innovation capabilities as crucial proficiencies for developing digital market offerings.

Concerning digital market offerings, an advantage may be a company's capability to generate and select productive ideas but also to have the requisite processes in place to advance novel products and services, coupled with a willingness to develop new solutions. Such a digitalrelated innovation capability may be difficult for competitors to imitate, potentially providing an initiation to digital market offerings. Thus, the following hypothesis was formulated:

H4: Innovation capabilities relate positively to digital market offerings.

\subsubsection{Effects of Digital-related Capabilities On the Business Process}

The increased digitalization of companies' operating environments provides possibilities for digital innovation to occur. As related to business processes, real-time activities and automated production processes (Fichman et al. 2014), for example, continuously affect the approach to development and innovation. New types of digital solutions provide broadened opportunities for data gathering, and different types of artificial intelligence solutions can assist companies and their employees and managers in decision making (Jarrahi 2018). This development of digital solutions creates circumstances in and by which different groups of people have increased options for generating digital innovations and affecting the business processes of companies. However, although developed digital solutions can provide enhanced data and support for development, analysis, and decision making, humans remain solely responsible for making decisions and generating digital innovations. As such, the capacity to effectively apply digital solutions and take advantage of the opportunities these solutions permit for developing business processes depends on companies possessing the requisite digital-related human capabilities. For this reason, companies must develop a culture and atmosphere that supports and promotes the development and utilization of their employees' digital skills.

Richter et al. (2018) further highlighted that, in the context of digital work design, companies must cultivate the understanding of which work practices allow work to be more autonomous while at the same time allowing employees to learn and collaborate with each other. Digital-related human capabilities ensure that the increased digitalization within companies can be easily accepted by employees. If the adopted digital solutions cannot be properly used and, for example, the collected data are not properly understood, then digital innovations cannot be generated. While real-time activities, artificial intelligence solutions, and automated production processes assist and support companies, they cannot effectively respond to common-sense situations (Guszcza et al. 2017; Jarrahi et al. 2018) or to the entire structure of the digital business process. Different types of digital solutions can assist in different aspects of the business process, but the combination of information derived from these aspects requires a common understanding of the digital business process, especially under uncertain conditions. As such, human capabilities and senses are still needed to correctly interpret the work generated by digital solutions (Brynjolfsson and McAfee 2012) and to convert such interpretations into digital innovations, and companies must therefore ensure that their employees are well trained in using digital solutions. Based on these arguments, the following hypothesis was developed:

H5: Human capabilities relate positively to the digital business process. 
Digital-related capabilities, in terms of collaborations like knowledge sharing, social media, digital makerspaces, and relationships in virtual worlds, have enabled digital innovations in business processes (Nambisan et al. 2017). In addition, due to the changes that digitalization has catalyzed in the implementation of business processes, it is necessary to reconsider cooperation among companies (Pagani and Pardo 2017). For instance, using three-dimensional constructs as digital tools in the construction process has created many different, unexpected collaborations and interactions between different partners, designers, and trades, which has in turn expanded innovation (Boland et al. 2007) while underscoring the need for collaboration capabilities. Therefore, advanced digital channels are required to encourage collaborative activities in the business process. Furthermore, different researchers have reconsidered digital tools as a facilitator of collaboration among business partners, which can be a challenging pursuit, one that often requires adaptations and new business models (Foltean et al. 2019; Nath et al. 2010).

Despite the potential that social media, as digital channels, have for transforming business processes (Foltean et al. 2019), most marketers have not fully distinguished them as either opportunities or threats with respect to the creation of new business (Cortez and Johnston 2017). For instance, Kietzmann and colleagues (2011) identified a lack of knowledge and/or skills with regard to the adoption of social media and the integration of related strategies in the business process (Kietzmann et al. 2011). As mentioned by Luo and colleagues (2010), despite the appeal of sharing knowledge, capabilities, and resources among partners, including external partners in the product development process often leads to greater coordination costs and integration difficulties. Thus, a successful digital business strategy requires effective cooperation among companies in terms of the product, process, and service domains, thereby rendering the enhancement of the exploitation of digital innovation more complex (Iansiti and Lakhani 2014). In addition to these issues, it is worth mentioning that the results achieved from cooperation in innovation strategies are not always positive due to involuntary knowledge spillovers, different learning speeds, divergent attitudes concerning the ultimate goal, and lack of flexibility and adaptability (Faems et al. 2005). Therefore, based on the abovementioned literature, the following hypothesis was formulated:

H6: Collaboration capabilities relate positively to the digital business process.

It has been suggested that digital ecosystems include artifacts and operations that increasingly derive utility from the functional relations they maintain (Kallinikos et al. 2013), as demonstrated by the growing prospects of combining software and software constituents and mixing content across platforms, infrastructures, and production systems
(Kallinikos et al. 2013; Langlois 2003; Merrifield et al. 2008; Yoo et al. 2010). All of this is possible via digital technologies that enable physical products to be programmable, addressable, sensible, communicable, memorable, traceable, and associable (Yoo 2010). These advances in digital technologies, in turn, permit developments in digital infrastructures toward the support of innovations in terms of figurative flexibility, semantic coherence, temporal and spatial traceability, knowledge brokering, and linguistic calibration. (Lyytinen et al. 2016). These types of technical capabilities allow the successful generation of novel information technology (IT)enabled products, services, and processes, whereby the process innovation outcomes refer to process redesign and simplification (productivity; Kohli and Melville 2019). Embedding digital technologies in the operations and productions of companies also allows online activities, both within the company and with the company's customers (Chen et al. 2015; Yoo et al. 2012).

Digital technologies are increasingly appearing in the industrial manufacturing context (Nylén and Holmström 2015). Instead of scheduled servicing, embedded digital capabilities allow the utilization of service forecasting and real-time monitoring (Nylén and Holmström 2015; Westergren and Holmström 2012). For example, with direct digital manufacturing (an interconnection between modern ICT and additive manufacturing equipment), it is possible to reconcile supply capacities and consumer demands in real time (Chen et al. 2015). Furthermore, the different forms of direct digital manufacturing include the potential for modifying material efficiency in product business models and process chains, and even in the product-user relationship (Chen et al. 2015). In sum, the current research suggests that the technical capabilities of digital technologies affect digital business processes in terms of, for instance, online activities and advanced manufacturing efficiency (Chen et al. 2015; Nylén and Holmström 2015; Yoo et al. 2012). In line with these considerations, the following hypothesis was proposed:

H7: Technical capabilities relate positively to the digital business process.

Responding to both the threats and opportunities posed by digitalization by initiating digital business processes also requires new capabilities in the area of innovation (Henfridsson and Yoo 2014; Sia et al. 2016). Since rapid changes in the business environment make innovation with digital technologies more demanding, various areas of business must be more organized (Lokuge et al. 2019) called this engaging in an innovation-savvy culture that contributes to digital innovation. Thus, this type of innovation capability, which assists companies in sharing information (Lokuge et al. 2019) that corresponds to the opportunities and threats caused by digitalization (Sia et al. 2016) and in applying digital technologies most relevant for their business (Nylen and Holmström 2015), 
becomes crucial. Further, digital innovation requires a culture that permits improvisational efforts throughout the company while simultaneously recognizing novel opportunities for innovation (Nylen and Holmström 2015).

With regard to digital business processes, innovation capabilities are also a key mechanism by which companies can exploit digital innovation. Digital business processes usually require companies to modify their current production or general business processes to enhance their functional efficiency. Therefore, it was expected that a company's innovation capability, i.e., its capability to generate and select ideas, advance novel products and services, and develop new solutions, is a crucial means by which it can exploit digital innovation. Thus, the following hypothesis was formulated:

H8: Innovation capabilities positively relate to the digital business process.

\section{Methodology}

\subsection{Sample and Data Collection}

This study used managers' perceptions as reported in data collected via a survey questionnaire of 280 SMEs operating in the service and manufacturing industries in Finland. As a sampling frame, the list from the random sampling of 6,816 Finnish SMEs was used; in 986 cases, the contact information was invalid, and thus the survey was ultimately conducted with 5,830 SMEs-30\% of the 20,0000 SMEs in Finland. Then, an invitation letter containing a direct link to the survey and a cover letter that described the purpose of the survey was sent by email to the managers of the Finnish SMEs, asking them to participate in the survey questionnaire. Four reminders were sent during the one-month data collection procedure, and ultimately a total of 280 valid responses was obtained, which is more than the minimum sample size suggested by Barlett et al. for certain populations (2001).

In terms of the respondents' characteristics, firm experience ranged from 2 to 123 years, with an average of 35.85 years, demonstrating that most of the companies were relatively mature in their fields. Approximately $70 \%$ of the companies in the sample were small enterprises with fewer than $49 \mathrm{em}-$ ployees, while the rest were medium-size enterprises. As mentioned above, all the sampled companies operate in the service (about $57 \%$ ) or manufacturing (about $42 \%$ ) industries. Table 1 outlines the demographic information of the respondents.

\subsection{Construct Operationalization}

The constructs were conceptualized as reflective measures. Those involved in the research model were measured on a 7-
Table 1 Demographic information of the respondents $(\mathrm{N}=280)$

\begin{tabular}{lll}
\hline Characteristics & Number of enterprises & Percentage (\%) \\
\hline Age (years since established) & 138 & 49.29 \\
fewer than 29 & 142 & 50.71 \\
more than 30 & & \\
Number of employees & 197 & 70.35 \\
Small (fewer than 49) & 78 & 27.85 \\
Medium (49-250) & 5 & 0.8 \\
No response & & \\
Sector & 160 & 57.14 \\
Service & 118 & 42.15 \\
Manufacturing & 2 & 0.71 \\
No response & & \\
\hline
\end{tabular}

point Likert type scale using multiple items, where a response of 1 indicated "strongly disagree" and 7 indicated "strongly agree." Due to the lack of empirical research on digital-related capabilities and digital innovation, specific scales had to be created based on previous literature, and new items were developed to measure both digital-related capabilities and digital innovation. To assess digital-related capabilities, four different digital-related capabilities, including human (El Sawy et al. 2016; Lerch and Gotsch 2015), collaboration (Amit and Han 2017; Chuang and Lin 2015; El Sawy et al. 2016), technical (El Sawy et al. 2016; Parida et al. 2015; Xue 2014), and innovation (Parida et al. 2015; Xue 2014) capabilities were developed as independent variables. Digital-related human capabilities consisted of three items addressing questions related to companies' supportive and encouraging attitude toward the development of digital skills, as well as to employees' level of training in digital tool usage and readiness in the digitalization of the operating environment (El Sawy et al. 2016; Lerch and Gotsch 2015). To measure digitalrelated collaboration capabilities, three items were defined to resolve questions related to the existence of digital cooperation with other companies, the utilization of digital channels to share information with other companies, and the extent to which digitalization has transformed the shape of social relationships in their business (Amit and Han 2017; Chuang and Lin 2015; El Sawy et al. 2016). For measuring digital-related technical capabilities, four items were included; in each case, digital technology was considered as an enabler, enhancing the value of both products and services; integrating products and services; working across boundaries of time, places, or activities; and providing up-to-date and borderless services (El Sawy et al. 2016; Parida et al. 2015; Xue 2014). To assess digital-related innovation capabilities, three items were developed, each addressing how digitalization enables innovations and new ideas, the development of new solutions, and the production of new products and services (Parida et al. 2015; Sia et al. 2016; Xue 2014). For measuring digital innovation, two noteworthy and concurrent phenomena, market offerings and business processes, were developed as dependent 
variables. Market offerings included two items addressing questions about whether digitalization can be defined as digital services and digital products (Nambisan et al. 2017; Nylén and Holmström 2015). To measure the business process, two items were developed, each posing questions about whether digitalization should be defined as automating production processes and real-time activities (Fichman et al. 2014). A complete list of items is presented in Appendix.

Three control variables were used to reduce the likelihood of confounded results occurring due to differences in company age and size, as well as in the type of industry (Bstieler 2005). In this research, firm size was measured by the number of employees, firm age was determined according to when the company was established, and type of industry was measured by asking respondents if their companies operated in either service or manufacturing.

\subsection{Data Analysis, Validity, and Reliability}

To confirm the reliability and validity of the data, and to reduce both common method bias and non-respondent bias, different approaches and statistical tests were used at each step of data collection and analysis, as the necessity of these approaches and tests has been suggested by Flynn et al. (1990). Regarding pre-tests, in an initial step, iterative sessions with expert researchers were held while designing the survey questionnaire, and the measured items were determined based on the theoretical foundation provided by previous research. Moreover, the items were constructed in such a way that the risk of recognition of a cause-and-effect relationship between the dependent and independent variables by the respondents was extremely low. In addition, the survey respondents were ensured anonymity, which encouraged them to respond more honestly and to resist the pressure to reply in a socially desirable way. Thus, in the initial phase, the probability of common method bias was minimized via these justifications. Furthermore, as suggested by MacKenzie and Podsakoff (2012), selecting respondents with the necessary experience in the relevant topic, avoiding the use vague concepts, and using clear and concise language reduce common method bias in survey research. Thus, to avoid common method bias, this study recruited respondents who were managers of the SMEs and had the necessary experience in digital innovation and disseminated a survey questionnaire in Finnish, the native language of all respondents. Regarding non-respondent bias, an analysis of the variance test (ANOVA) was conducted to determine whether any significant differences existed between the respondents' answers on the questionnaire after the first reminder, called early respondents, and their answers after the third reminder, named late respondents (Armstrong and Overton 1977). The results revealed that there was no significant difference between these two groups. Therefore, due to the application of all these approaches, the study results were not at risk of common-method bias, late-respondent bias, or lack of validity and reliability.

Prior to the hypothesis tests, the reliability and convergent and discriminant validity of the constructs were tested with confirmatory factor analysis (CFA) and different indices, including loadings, Cronbach' alpha, average variance extracted (AVE), and composite reliability (CR), as shown in Table 2. First, Cronbach's alpha was used to assess the items' reliability. Although a value of 0.7 or 0.6 is recommended as the acceptable cutoff for Cronbach's alpha (Taber 2018) in both exploratory research (Boyer and Pagell 2000) and in the development of new constructs (Flynn et al. 1990; Nunnally 1978) mentioned that a smaller value is permissible if the scales are new and contain a small number of items. As shown in Table 2, all the constructs except market offerings had values greater than 0.6 , illustrating the reliability of the constructs. Principal component analysis (PCA) is loaded in one factor with an eigenvalue greater than 1; this suggested for items representing a single unidimensional construct, and if the constructs have the factor loadings greater than 0.4, they are shown to be valid (Carmines and Zeller 1979). Convergent validity was verified by the value of the factor loadings, AVE and CR. As suggested by Fornell and Larcker (1981), the convergent validity of the construct is still adequate for an AVE less than 0.5 if the $\mathrm{CR}$ is higher than 0.6. As shown in Table 2, each loading had a value of more than 0.4 , and the value of the AVE for all the constructs except business process (AVE = $0.482)$ and market offerings $(\mathrm{AVE}=0.428)$ was more than 0.5 , which, in this case, because the CR values were more than 0.6 , the convergent validity of the constructs was confirmed. Discriminant validity was supported by collating the AVE and maximum shared variance (MSV) values, which showed that all the values of MSV were smaller than those of the AVE.

A correlation matrix was used to assess the validity of the constructs; the results are presented in Table 3 . Multicollinearity was assessed by calculating the variance inflation factors (VIFs) and tolerance values among the independent variables. As recommended by Kleinbaum et al. (1988), multicollinearity is not an issue if the VIF value is lower than a threshold of 5-10 and has a tolerance greater than 0.2 ; in this study, all the VIF values were in the range of 1.061-2.881 with a tolerance greater than 0.3 . As suggested by Fornell and Larcker (1981), the discriminant validity of the constructs can be confirmed if the value of the square root of AVE is greater than the value of the correlation between constructs. Comparing the diagonal with non-diagonal values in Table 3 confirmed the convergent validity of the constructs. Therefore, multicollinearity and convergent validity were not a significant concern in this study, as the requirements of all the recommended statistical tests were met. 
Table 2 Results of validity and reliability testing

\begin{tabular}{|c|c|c|c|c|c|}
\hline Latent variable & Observed variable & Loadings & Cronbach' $\alpha$ & AVE & $\mathrm{CCR}$ \\
\hline \multirow[t]{2}{*}{ Human capabilities } & $\begin{array}{l}\text { Digital skills development is supported and promoted in our company. } \\
\text { Our employees are well trained in using digital tools. }\end{array}$ & $\begin{array}{l}0.778 \\
0.718\end{array}$ & \multirow[t]{2}{*}{0.772} & \multirow[t]{2}{*}{0.514} & \multirow[t]{2}{*}{0.760} \\
\hline & Digitalization of the operating environment is easily accepted by our employees. & 0.649 & & & \\
\hline \multirow[t]{2}{*}{ Collaboration capabilities } & $\begin{array}{l}\text { Digital cooperation with other companies occurs. } \\
\text { Digital channels are used to share information with other companies. }\end{array}$ & $\begin{array}{l}0.882 \\
0.824\end{array}$ & \multirow[t]{2}{*}{0.799} & \multirow[t]{2}{*}{0.597} & \multirow[t]{2}{*}{0.812} \\
\hline & Digitality transforms the social relationships in our business. & 0.578 & & & \\
\hline Technical capabilities & $\begin{array}{l}\text { Digitality increases the value of our products or services. } \\
\text { Digitality enables the integration of products and services into our company. } \\
\text { Digitality enables up-to-date, location-independent services for our customers. } \\
\text { Digitality allows us to work across boundaries of time, place, or activities. }\end{array}$ & $\begin{array}{l}0.856 \\
0.874\end{array}$ & 0.862 & 0.623 & 0.867 \\
\hline \multirow[t]{2}{*}{ Innovation capabilities } & $\begin{array}{l}\text { Digitality enables innovation and new ideas in our company. } \\
\text { Digitality forces us to develop new solutions. }\end{array}$ & $\begin{array}{l}0.878 \\
0.745\end{array}$ & \multirow[t]{2}{*}{0.859} & \multirow[t]{2}{*}{0.679} & \multirow[t]{2}{*}{0.864} \\
\hline & Digitality helps produce new products and services. & 0.844 & & & \\
\hline Business process & $\begin{array}{l}\text { Digitalization refers to real-time activities. } \\
\text { Digitalization refers to the automation of the production process. }\end{array}$ & $\begin{array}{l}0.630 \\
0.754\end{array}$ & 0.638 & 0.482 & 0.666 \\
\hline Market offerings & $\begin{array}{l}\text { Digitalization refers to digital services. } \\
\text { Digitalization refers to digital products. }\end{array}$ & $\begin{array}{l}0.666 \\
0.643\end{array}$ & 0.591 & 0.428 & 0.616 \\
\hline
\end{tabular}

\section{Results}

Partial least squares (PLS)-based structural equation modeling (SEM) was used to test the hypotheses (SmartPLS v. 3.3.1). Smart PLS has frequently been recommended due to its accuracy and overall utility (Chuang and Lin 2015). SEM is suitable for data with multiple groups of regression, in which the dependent variable for one regression analysis is simultaneously an independent variable for another (Hair et al. 1998). Thus, Aside from its capacity to handle multiple groups, PLS SEM can also be applied flexibly to both formative and reflective constructs and, additionally, is undemanding in terms of measurement scales, sample size, and distributional assumptions" depending on the intended meaning (Chuang and Lin 2015). Moreover, the PLS path models used in top tier journals are based on a significance level of 0.1 (Hair et al. 2012). Table 4 lists the testing paths from digitalrelated capabilities to digital innovation.
The first model was able to explain $47 \%$ of the variance in digital market offerings and $29 \%$ of the variance in digital business process. The path from technical capabilities $(\mathrm{B}=$ $0.617, p \leq 0.10$ ) to digital market offerings was significant, whereas the paths from human capabilities $(\mathrm{B}=-0.215$, ns), innovation capabilities $(\mathrm{B}=0.050, \mathrm{~ns})$, and collaboration capabilities ( $\mathrm{B}=0.239, \mathrm{~ns})$ to digital market offerings were nonsignificant. Thus, technical capabilities had a direct positive impact on digital market offerings, whereas human capabilities, innovation capabilities, and collaboration capabilities did not. The path from human capabilities $(B=0.559, \mathrm{p} \leq 0.01)$ to digital business process was significant, whereas the paths from technical capabilities ( $\mathrm{B}=-0.447$, ns), innovation capabilities $(\mathrm{B}=0.482, \mathrm{~ns})$, and collaboration capabilities $(\mathrm{B}=$ 0.083 , ns) to digital business process were non-significant. Thus, human capabilities had a direct positive impact on digital market offerings, whereas technical capabilities, innovation capabilities, and collaboration capabilities did not.

Table 3 Correlation matrix

\begin{tabular}{|c|c|c|c|c|c|c|}
\hline & $\begin{array}{l}\text { Human } \\
\text { capabilities }\end{array}$ & $\begin{array}{l}\text { Collaboration } \\
\text { capabilities }\end{array}$ & $\begin{array}{l}\text { Technical } \\
\text { capabilities }\end{array}$ & $\begin{array}{l}\text { Innovation } \\
\text { capabilities }\end{array}$ & Market offerings & Business process \\
\hline Human capabilities & $0.717^{\mathrm{a}}$ & & & & & \\
\hline $\begin{array}{l}\text { Collaboration } \\
\text { capabilities }\end{array}$ & $0.543^{* *}$ & $0.773^{\mathrm{a}}$ & & & & \\
\hline Technical capabilities & $0.591 * *$ & $0.525 * *$ & $0.789^{\mathrm{a}}$ & & & \\
\hline Innovation capabilities & $0.533 * *$ & $0.568 * *$ & $0.775 * *$ & $0.824^{\mathrm{a}}$ & & \\
\hline Market offerings & $0.303 * *$ & $0.355 * *$ & $0.464 * *$ & $0.445 * *$ & $0.694^{\mathrm{a}}$ & \\
\hline Business process & $0.332 * *$ & $0.232 * *$ & $0.255^{* *}$ & $0.305 * *$ & 0.073 & $0.654^{\mathrm{a}}$ \\
\hline
\end{tabular}

${ }^{\mathrm{a}}$ Square root of AVE, Sign. $* * * \leq 0.001, * * 0.001<p \leq 0.01, * 0.01<p \leq 0.05$ 
Table 4 Testing the paths from digital-related capabilities to digital innovation

\begin{tabular}{|c|c|c|}
\hline Path & Path coefficient & t-value \\
\hline \multicolumn{3}{|l|}{ Model 1} \\
\hline Human capabilities $->$ Market offerings & -0.215 & 1.094 \\
\hline Technical capabilities $->$ Market offerings & 0.617 & $1.730^{*}$ \\
\hline Innovation capabilities -> Market offerings & 0.050 & 0.146 \\
\hline Collaboration capabilities -> Market offerings & 0.239 & 1.263 \\
\hline Human capabilities $->$ Business process & 0.559 & $3.017 * *$ \\
\hline Technical capabilities $->$ Business process & -0.447 & 1.524 \\
\hline Innovation capabilities $->$ Business process & 0.482 & 1.579 \\
\hline Collaboration capabilities -> Business process & -0.083 & 0.433 \\
\hline \multicolumn{3}{|l|}{ Model 2} \\
\hline Technical capabilities -> Market offerings & 0.675 & $7.842 * * *$ \\
\hline Human capabilities $->$ Technical capabilities & 0.278 & $3.374 * * *$ \\
\hline Innovation capabilities -> Technical capabilities & 0.776 & $9.917 * * *$ \\
\hline Collaboration capabilities -> Technical capabilities & -0.095 & 1.079 \\
\hline \multicolumn{3}{|l|}{ Model 3} \\
\hline Human capabilities $->$ Business process & 0.499 & $5,730 * * *$ \\
\hline Technical capabilities -> Human capabilities & 0.691 & $3,035^{* *}$ \\
\hline Innovation capabilities -> Human capabilities & -0.200 & 0,780 \\
\hline Collaboration capabilities $->$ Human capabilities & 0.389 & $3,795 * * *$ \\
\hline
\end{tabular}

Notes: $* * *$ Significance $\leq 0.001 ; * *$ Significance $\leq 0.01 ; *$ Significance $\leq 0.10$

The second model was able to explain $43 \%$ of the variance in digital market offerings. The path estimates of this model provide further insight into hypotheses $1-4$. The path from technical capabilities $(B=0.675, p \leq 0.001)$ to digital market offerings was significant, as in the first model. The paths from human capabilities $(B=0.278, p \leq 0.001)$ and innovation capabilities $(B=0.776, p \leq 0.001)$ to technical capabilities were also significant. Thus, human capabilities and innovation capabilities both had a significant positive impact on digital market offerings through technical capabilities. The research model also predicted a mediated path from collaboration capabilities $(\mathrm{B}=-0.095, \mathrm{~ns})$ to digital market offerings. However, this path was not supported.

The third model was able to explain $25 \%$ of the variance in digital business process. The path estimates of this model provide further insight into hypotheses 5-8. The path from human capabilities $(B=0.499, p \leq 0.001)$ to digital business process was significant, as in the first model. The paths from technical capabilities $(B=0.691, p \leq 0.01)$ and collaboration capabilities $(B=0.389, p \leq 0.001)$ to human capabilities were also significant. Thus, technical capabilities and collaboration capabilities both had a significant positive impact on digital business process through human capabilities. The research model also predicted a mediated path from innovation capabilities ( $\mathrm{B}=-0.200, \mathrm{~ns})$ to digital business process. However, this path was not supported. A summary of the results is presented in Table 5.

\section{Discussion}

Digital transformation is shaping the business environments of contemporary companies and Big Data analytics and digital business ecosystems are providing increasingly new possibilities for companies to develop their businesses; therefore, companies need to be able to respond to the changes and understand the possibilities provided by increased digitalization (Delgosha et al. 2020; Mikalef et al. 2020; Pappas et al. 2018). Companies need to find ways to exploit innovation in digitalizing business environments (Bednar and Welch 2019; Mikalef et al. 2018) and to understand the role of different types of capabilities as a part of these activities (Mikalef et al. 2019).

The study aimed to investigate what digital-related capabilities are required to shape the exploitation of digital innovation, namely digital market offerings and the digital business process. The results demonstrated that human, technical, and innovation capabilities contribute to digital market offerings, while human, collaborative, and technical capabilities contribute to the digital business process. These findings suggest that the studied capabilities play a significant role in the reshaping and digitizing of an organization in a way that enables new digital innovations. These results are consistent with research from Gobble (2018) that stated that the processes of digitalization and digital transformation may start as 
Table 5 Summary of the results

\begin{tabular}{|c|c|c|}
\hline Proposition & Support & Interpretation \\
\hline $\begin{array}{l}\text { H1: Human capabilities relate positively to } \\
\text { digital market offerings. }\end{array}$ & Supported & $\begin{array}{l}\text { Human capabilities contribute indirectly to digital innovation in terms of digital market } \\
\text { offerings. Human capabilities enhance technical capabilities, which in turn contribute to } \\
\text { digital market offerings. }\end{array}$ \\
\hline $\begin{array}{l}\text { H2: Collaboration capabilities relate positively } \\
\text { to digital market offerings. }\end{array}$ & $\begin{array}{l}\text { Not } \\
\text { sup- } \\
\text { ported }\end{array}$ & $\begin{array}{l}\text { Collaboration capabilities do not facilitate the creation of digital innovation in terms of } \\
\text { digital market offerings. }\end{array}$ \\
\hline $\begin{array}{l}\text { H3: Technical capabilities relate positively to } \\
\text { digital market offerings. }\end{array}$ & Supported & $\begin{array}{l}\text { Technical capabilities directly contribute to the extent to which companies are able to create } \\
\text { digital innovation in terms of digital market offering. }\end{array}$ \\
\hline $\begin{array}{l}\text { H4: Innovation capabilities relate positively to } \\
\text { digital market offerings. }\end{array}$ & Supported & $\begin{array}{l}\text { Innovation capabilities contribute indirectly to digital innovation in terms of digital market } \\
\text { offering. Innovation capabilities enhance technical capabilities, which in turn contribute } \\
\text { to digital market offering. }\end{array}$ \\
\hline $\begin{array}{l}\text { H5: Human capabilities relate positively to the } \\
\text { digital business process. }\end{array}$ & Supported & $\begin{array}{l}\text { Human capabilities directly contribute to the extent to which companies are able to create } \\
\text { digital innovation in terms of the digital business process. }\end{array}$ \\
\hline $\begin{array}{l}\text { H6: Collaboration capabilities relate positively } \\
\text { to the digital business process. }\end{array}$ & Supported & $\begin{array}{l}\text { Collaboration capabilities contribute indirectly to digital innovation in terms of the digital } \\
\text { business process. Collaboration capabilities enhance human capabilities, which in turn } \\
\text { contribute to the digital business process. }\end{array}$ \\
\hline $\begin{array}{l}\text { H7: Technical capabilities relate positively to } \\
\text { the digital business process. }\end{array}$ & Supported & $\begin{array}{l}\text { Technical capabilities contribute indirectly to digital innovation in terms of the digital } \\
\text { business process. Technical capabilities enhance human capabilities, which in turn } \\
\text { contribute to the digital business process. }\end{array}$ \\
\hline $\begin{array}{l}\text { H8: Innovation capabilities relate positively to } \\
\text { the digital business process. }\end{array}$ & $\begin{array}{l}\text { Not } \\
\text { sup- } \\
\text { ported }\end{array}$ & $\begin{array}{l}\text { Innovation capabilities do not facilitate the creation of digital innovation in terms of the } \\
\text { digital business process. }\end{array}$ \\
\hline
\end{tabular}

innovation initiatives, but they ultimately must reach far beyond the innovation function to reshape the entire organization. One of the main results of this study was that human capabilities directly contribute to the extent to which companies can create digital innovation through digital business processes. This result strongly supports the findings from Rachinger et al. (2019). This research studied representatives from two different industries and found that, from a capability perspective, digitalization requires human skills (Rachinger et al. 2019). The authors also pointed out challenges in the areas of employee recruitment and qualification, and they highlighted the importance of companies' ability to develop the know-how required to seize digitalization opportunities (Arnold et al. 2016; Rachinger et al. 2019). Therefore, while digital transformation provides novel opportunities for companies, it also requires an understanding of which capabilities are required and how those capabilities should be adapted with regard to innovation outcomes, processes, and related markets (Kohli and Melvill 2019; Nambisan et al. 2017). In the following sections, the implications of the results for theory and practice are presented in detail.

\subsection{Implications for Theory}

Referring to digital innovation in terms of market offerings, technical capabilities have significant direct effects on dig- ital market offerings; in contrast, no direct effects were found for human, collaboration, and innovation capabilities. Thus, this finding strongly supports prior statements that technical capabilities are the main enablers of organizational capabilities toward digital innovation (Banker et al. 2006; Mithas et al. 2011; Setia et al. 2013; Tanriverdi 2005). One explanation for this finding is that digital technology creates a bond between the physical and digital characteristics of products and services, as presented by El Sawy et al. (2016). In addition, the technical capabilities surrounding digital technologies relate to the value propositions of digital products and services, addressing how value is generated and captured in each digital product and service (Nylén and Holmström 2015). For H3, the present research findings are in line with those of former studies, indicating that, because of the growing and increasingly ubiquitous presence of digital technologies at a reasonable cost, factors hindering market offerings will be removed. Consequently, the exploitation of products and services will be facilitated with integrated products and services, as well as with updated and borderless activities (Nylén and Holmström 2015; Sjödin et al. 2016; Yoo et al. 2010). The findings also support previous statements that technical capabilities permit activities to cross the boundaries of time, place, and function (Parida et al. 2015; Yoo 2010; Yoo et al. 2012) and provide the potential to reinvent sales and distribution channels (Nylén and Holmström 
2015). This result suggests that technical digital-related capabilities play a lead role in the provision and exploitation of market offerings.

Referring to H1, the results of the study support previous research by indicating the complementary role of digital-related human capabilities and continuous learning in digitalizing operating environments (Nylen and Holmströn 2015) and in launching new products in digital business (Fuchs and Sevignani 2013). Although human capabilities in terms of employee readiness and digital skills play a role in the shift toward digitalization (Chan et al. 2019; El Sawy et al. 2016; Kane et al. 2015; Legner et al. 2017), they do not directly reshape and exploit market offerings. Instead, the effect takes place through technical capabilities. This means that skills related to understanding user experience and customer wishes and needs (Hoe 2017; Nylén and Holmström 2015) are being deployed to use and select the technology needed to realize digital innovation.

Regarding H2, the findings show that collaboration capabilities do not facilitate the creation of digital innovation in terms of digital market offerings. This is contrary to the predominant view in extant literature, which suggests that successful market offerings in the blurry and complex arena of digitalization need collaboration, and that it is not possible to be successful in a vacuum-like business environment (Canhoto et al. 2016; Kohli and Mekville 2019; Lyytinen et al. 2016; Pagani and Pardo 2017). This may be because digital technology is affordable and more ubiquitous than ever before, which may in turn facilitate internal development and engagement in digital innovation (cf. Nylén and Holmström 2015; Yoo et al. 2010). Additionally, digital technologies provide more sophisticated and easy-to-use tools that together present opportunities for automatizing products and making services smarter. This can in turn encourage companies to be less dependent on their partners and thereby reduce the importance of collaboration.

In terms of $\mathrm{H} 4$, the results support the findings covered in previous research that indicate that innovation capabilities are key organizational capabilities for creating new products and services (Sia et al. 2016; Sousa and Rocha 2019). The current findings are also in line with those of Nylén and Holmström (2015), who argued that exploiting novel opportunities for innovation is key to generating a compiled value via the creation of digital products and services. However, like human capabilities (H1), innovation capabilities do not directly reshape and exploit market offerings. The effect actually takes place through technical capabilities. The explanation for the mediation effect may be related to Fichman et al.'s (2014) earlier argument, in which digital innovation was claimed to require an understanding of what has become possible due to advances in technology, as well as the exploitation of this understanding to create something valuable for the company or for society. Overall, this finding illustrates the important role of innovation capabilities in the exploitation of market offerings.
Concerning digital innovation in terms of business process, digital-related capabilities related to the human element had a direct significant effect on the digital business process, whereas direct significant effects of collaboration, technical, and innovation capabilities on the digital business process were not found. However, collaboration and technical capabilities had a mediating effect between human capabilities and the digital business process. The reason why human capabilities have a predominant role may be the dynamic and cognitive nature of digital business processes, which are more compatible with human capabilities in comparison to others. Although a variety of digital solutions provide possibilities for data gathering, and different types of artificial intelligence solutions can assist companies, employees, and managers in decision making, as presented by Jarrahi (2018), humans remain the sole authority for making decisions and generating digital innovations. For H5, this study supports the view of previous research, which suggested that employees' digital skills and readiness to exploit the digital business process (Richter et al. 2018) can be used to interpret the work generated by digital solutions (Brynjolfsson and McAfee 2012). These findings are in line with the notion that while realtime activities, artificial intelligence solutions, and automated production processes assist and support companies, they cannot handle common-sense situations (Guszcza et al. 2017; Jarrahi et al. 2018) nor the entire structure of the digital business process. Digital solutions can assist in different aspects of the business process, but the combination of information derived from these aspects requires a common understanding of the digital business process, which can be advanced by human capabilities. Hence, this finding confirms the important role of human capabilities in moving toward digitalization in the digital business process.

Referring to H6, collaboration capabilities do not have a direct effect on the digital business process. This may be because of the complex nature of collaboration in digital channels (Boland et al. 2007; Foltean et al. 2019; Iansiti and Lakhani 2014; Nath et al. 2010), the lack of skills needed for collaborating with other companies via digital channels in activities that are more related to business processes (Kietzmann et al. 2011), and the coordination costs and integration difficulties in the product development process (Luo et al. 2010). However, collaboration capabilities facilitate the business process through human capabilities. The role of collaboration capabilities can thus be highlighted, since they advance human capabilities, which in turn positively affect the business process.

In terms of $\mathrm{H} 7$, the study results do not directly support the hypothesis. In contrast to previous research that mentioned the role of technical capabilities in digital business processes and operations (Chen et al. 2015; Nylén and Holmström 2015; Westergren and Holmström 2012; Yoo et al. 2012), the present study did not discover a direct significant relationship 
between technical capabilities and digital business processes. The reason for this may be the collective nature of technical capabilities and the lack of linkages among companies using real-time activities. However, path modelling indicated that technical capabilities affect digital business processes through human capabilities. Technical capabilities can thus be considered as valuable drivers for human capabilities, which enable the successful generation of novel information technologyenabled products, services, and processes, whereby the process innovation outcomes refer to the redesign and simplification of the business process (cf. Kohli and Melville 2019).

Finally, concerning H8, this study did not support previous research indicating that innovation capabilities facilitate the creation of digital innovation in terms of digital business processes. As mentioned in previous research, innovation capabilities assist companies in sharing information (Lokuge et al. 2019), corresponding to the opportunities and threats caused by digitalization (Sia et al. 2016), and appropriating digital technologies relevant for their business activities (Nylen and Holmström 2015). However, the results of this study may indicate that innovation capabilities offer opportunities for other types of digital innovation, such as digital market offerings, rather than business process innovation.

\subsection{Implications for Practice}

The findings of this research provide valuable insights for managers interested in establishing required digital-related capabilities to develop and exploit digital innovations, including both market offerings and business processes in their business. First, the vision of digitalization in this study may help managers to perceive of their companies and nearby environments as a universal network, in which human, innovation, and especially technical capabilities can create more opportunities and potentials for the effective exploitation of market offerings. Therefore, in the current digital era, managers may need to focus more on these capabilities for enhancing their market offerings in terms of digital products and services, as they are more likely to lead to the achievement of competitive advantages. Second, managers in charge of digital innovation should consider and shape types of digital innovation in a way that is compatible with the nature of digital-related capabilities. For example, digital innovation in terms of market offerings involves technology-related actions; thus, shaping market offerings requires technology understanding, such as digital-related capabilities emphasizing human, innovation, and technical skills. In contrast, business processes in companies are more dynamic and cognitive actions. Therefore, these capabilities make human digital-related capabilities more applicable in this regard. Third, managers in charge of digital transformation should better familiarize employees to and attune working environments for digitalization; in addition, managers should work to enhance digital culture, and they should concentrate more on digital-related human capabilities in order to obtain more benefits and the greater exploitation of digital innovation in terms of the business process. Finally, SME managers should consider the major role of technical capabilities in digital innovation, namely market offerings, as well as the dominant role of human capabilities in digital innovation, namely the business process.

\section{Conclusion}

The aim of this research was to explore the conditions under which digital innovation opportunities emerge in SMEs. Furthermore, the research identified the required capabilities in digital transformation and understand the way of utilizing those capabilities to exploit digital innovation. Thus, the study answered the question of what capabilities are required to shape the exploitation of digital innovation. As a first contribution, this research adds to the process perspective of digital innovation. Few studies have concentrated on firm-level capabilities to identify, assimilate, and apply valuable knowledge from inside and outside the firm regarding opportunities for digital innovation, known as initiate activity (Kohli and Melville 2019). Further, this research extends the digital innovation literature by incorporating the effects of digital-related capabilities based on digital innovation type. The findings demonstrated that digital market offerings require technical-, human-, and innovation-related digital capabilities. In contrast, the digital business process requires digital-related capabilities in terms of human, technical, and collaboration. Since the results showed that the capabilities required for the adoption of digital innovation differ notably across the two digital innovation types, future research in this area should consider the digital innovation types separately.

This study had some limitations; however, these limitations can serve as the foundation for future research opportunities. First, the cross-sectional nature of the research imposed a limit on understanding over time; simultaneously, however, it provided the possibility for longitudinal research in the future. Second, the provision of data from a single country as well as the focus on managers' perceptions restricted the study's generalizability and increased the potential for bias; at the same time, however, these limitations present opportunities to replicate this study in other countries and with other resources. As mentioned above, many different methodological adjustments were made to correct or mitigate bias-related issues. Third, the low reliability of the outcome measures may have influenced the research results. A smaller value of alpha is permissible if the scales are new and contain a small number of items (Nunnally 1978); however, there is a need for a systematic approach to tackle this issue. Finally, since the study specialized in digital business processes inside companies, there is certainly more room for future research that would 
seek to link business processes outside the organization by utilizing real-time activities and digital twinning, as well as via collaboration among companies.

Funding Open access funding provided by LUT University.

\section{Appendix}

Table 6 Items and their measurement

\begin{tabular}{|c|c|c|c|c|}
\hline $\begin{array}{l}\text { Latent } \\
\text { variable }\end{array}$ & Observed variable & References* & $\begin{array}{l}\text { Type of } \\
\text { measurement }\end{array}$ & Scale \\
\hline $\begin{array}{l}\text { Human } \\
\text { capabilities }\end{array}$ & $\begin{array}{l}\text { Digital skills development is supported and } \\
\text { promoted in our company. } \\
\text { Our employees are well trained in using } \\
\text { digital tools. } \\
\text { Digitalization of the operating environment } \\
\text { is easily accepted by our employees. }\end{array}$ & $\begin{array}{l}\text { El Sawy et al. 2016; Lerch and } \\
\text { Gotsch } 2015\end{array}$ & Reflective & $\begin{array}{l}\text { 7-point scale ranging from "strongly } \\
\text { disagree" (1) to "strongly agree" (7) }\end{array}$ \\
\hline $\begin{array}{r}\text { Collaborative } \\
\text { capabilities }\end{array}$ & $\begin{array}{l}\text { Digital cooperation with other companies } \\
\text { occurs. } \\
\text { Digital channels are used to share } \\
\text { information with other companies. } \\
\text { Digitality transforms the social } \\
\text { relationships in our business. }\end{array}$ & $\begin{array}{l}\text { Amit and Han 2017; Chuang and } \\
\text { Lin 2015; El Sawy et al. } 2016\end{array}$ & Reflective & $\begin{array}{l}\text { 7-point scale ranging from "strongly } \\
\text { disagree" (1) to "strongly agree" (7) }\end{array}$ \\
\hline $\begin{array}{l}\text { Technical } \\
\text { capabilities }\end{array}$ & $\begin{array}{l}\text { Digitality increases the value of our } \\
\text { products or services. } \\
\text { Digitality enables the integration of } \\
\text { products and services into our company. } \\
\text { Digitality enables up-to-date, } \\
\text { location-independent services for our } \\
\text { customers. } \\
\text { Digitality allows us to work across } \\
\text { boundaries of time, place, or activities. }\end{array}$ & $\begin{array}{l}\text { El Sawy et al. 2016; Parida et al. } \\
\text { 2015; Xue } 2014\end{array}$ & Reflective & $\begin{array}{l}\text { 7-point scale ranging from "strongly } \\
\text { disagree" (1) to "strongly agree" (7) }\end{array}$ \\
\hline $\begin{array}{l}\text { Innovation } \\
\text { capabilities }\end{array}$ & $\begin{array}{l}\text { Digitality enables innovation and new } \\
\text { ideas in our company. } \\
\text { Digitality forces us to develop new } \\
\text { solutions. } \\
\text { Digitality helps produce new products and } \\
\quad \text { services. }\end{array}$ & $\begin{array}{c}\text { Parida et al. 2015; Sia et al. 2016; } \\
\text { Xue } 2014\end{array}$ & Reflective & $\begin{array}{l}\text { 7-point scale ranging from "strongly } \\
\text { disagree" (1) to "strongly agree" (7) }\end{array}$ \\
\hline $\begin{array}{l}\text { Business } \\
\text { processes }\end{array}$ & $\begin{array}{l}\text { In our company, digitalization refers to } \\
\text { real-time activities. } \\
\text { In our company, digitalization refers to the } \\
\text { automation of the production process. }\end{array}$ & Fichman et al. 2014 & Reflective & $\begin{array}{l}\text { 7-point scale ranging from "strongly } \\
\text { disagree" (1) to "strongly agree" (7) }\end{array}$ \\
\hline $\begin{array}{l}\text { Market } \\
\text { offerings }\end{array}$ & $\begin{array}{l}\text { In our company, digitalization refers to } \\
\text { digital services. } \\
\text { In our company, digitalization refers to } \\
\text { digital products. }\end{array}$ & $\begin{array}{c}\text { Nambisan et al. 2017; Nylén and } \\
\text { Holmström } 2015\end{array}$ & Reflective & $\begin{array}{l}\text { 7-point scale ranging from "strongly } \\
\text { disagree" (1) to "strongly agree" (7) }\end{array}$ \\
\hline
\end{tabular}

Note: *All the observed variables were developed based on the mentioned references. Thus, existing observed variables or implications of the mentioned studies were used as a reference to formulate new laten variables suitable for the current study 
Open Access This article is licensed under a Creative Commons Attribution 4.0 International License, which permits use, sharing, adaptation, distribution and reproduction in any medium or format, as long as you give appropriate credit to the original author(s) and the source, provide a link to the Creative Commons licence, and indicate if changes were made. The images or other third party material in this article are included in the article's Creative Commons licence, unless indicated otherwise in a credit line to the material. If material is not included in the article's Creative Commons licence and your intended use is not permitted by statutory regulation or exceeds the permitted use, you will need to obtain permission directly from the copyright holder. To view a copy of this licence, visit http://creativecommons.org/licenses/by/4.0/.

\section{References}

Ahmad, S., Mallick, D. N., \& Schroeder, R. G. (2013). New product development: impact of project characteristics and development practices on performance. Journal of Product Innovation Management, 30(2), 331-348.

Amit, R., \& Han, X. (2017). Value creation through novel resource configurations in a digitally enabled world. Strategic Entrepreneurship Journal, 11(3), 228-242.

Armstrong, J. S., \& Overton, T. S. (1977). Estimating nonresponse bias in mail surveys. Journal of Marketing Research, 14, 396-402.

Arnold, C., Kiel, D., \& Voigt, K. I. (2016). How the industrial internet of things changes business models in different manufacturing industries. International Journal of Innovation Management, 20(8), 1640015-1-1640015-25.

Banker, R. D., Bardhan, I. R., Chang, H., \& Lin, S. (2006). Plant information systems, manufacturing capabilities, and plant performance. MIS Quarterly, 30(2), 315-337.

Barlett, J. E., Kotrlik, J. W., \& Higgins, C. C. (2001). Organizational research: Determining appropriate sample size in survey research. Information Technology, Learning, and Performance Journal, 19(1), 43-50.

Bednar, P. M., \& Welch, C. (2019). Socio-technical perspectives on smart working: Creating meaningful and sustainable systems. Information Systems Frontiers, 22, 1-18.

Boland, R. J., Jr., Lyytinen, K., \& Yoo, Y. (2007). Wakes of innovation in project networks: The case of digital 3-D representations in architecture, engineering, and construction. Organization Science, 18(4), 631-647.

Bouwman, H., Nikou, S., \& de Reuver, M. (2019). Digitalization, business models, and SMEs: How do business model innovation practices improve performance of digitalizing SMEs? Telecommunications Policy, 43(9), 101828.

Boyer, K. K., \& Pagell, M. (2000). Measurement issues in empirical research: improving measures of operations strategy and advanced manufacturing technology. Journal of Operations Management, 18(3), 361-374.

Brynjolfsson, E., Hu, Y., \& Smith, M. D. (2010). Research commentary-long tails vs. superstars: The effect of information technology on product variety and sales concentration patterns. Information Systems Research, 21(4), 736-747.

Brynjolfsson, E., \& McAfee, A. (2012). Winning the race with eversmarter machines. MIT Sloan Management Review, 53(2), 53-60.

Bstieler, L. (2005). The moderating effect of environmental uncertainty on new product development and time efficiency. Journal of Product Innovation Management, 22(3), 267-284.

Canhoto, A. I., Quinton, S., Jackson, P., \& Dibb, S. (2016). The coproduction of value in digital, university-industry R \& D collaborative projects. Industrial Marketing Management, 56, 86-96.
Carmines, E. G., \& Zeller, R. A. (1979). Reliability and validity assessment (Vol. 17). Thousand Oaks: Sage publications.

Cenamor, J., Parida, V., \& Wincent, J. (2019). How entrepreneurial SMEs compete through digital platforms: The roles of digital platform capability, network capability and ambidexterity. Journal of Business Research, 100, 196-206.

Chan, C. M., Teoh, S. Y., Yeow, A., \& Pan, G. (2019). Agility in responding to disruptive digital innovation: Case study of an SME. Information Systems Journal, 29(2), 436-455.

Chen, D., Heyer, S., Ibbotson, S., Salonitis, K., Steingrímsson, J. G., \& Thiede, S. (2015). Direct digital manufacturing: definition, evolution, and sustainability implications. Journal of Cleaner Production, 107, 615-625.

Chuang, S. H., \& Lin, H. N. (2015). Co-creating e-service innovations: Theory, practice, and impact on firm performance. International Journal of Information Management, 35(3), 277-291.

Cortez, R. M., \& Johnston, W. J. (2017). The future of B2B marketing theory: A historical and prospective analysis. Industrial Marketing Management, 66, 90-102.

Davila, T., Epstein, M., \& Shelton, R. (2012). Making innovation work: How to manage it, measure it, and profit from it. FT press.

Delgosha, M. S., Saheb, T., \& Hajiheydari, N. (2020). Modelling the asymmetrical relationships between digitalisation and sustainable competitiveness: a cross-country configurational analysis. Information Systems Frontiers. https://doi.org/10.1007/s10796020-10029-0.

El Sawy, O. A., Kræmmergaard, P., Amsinck, H., \& Vinther, A. L. (2016). How LEGO built the foundations and enterprise capabilities for digital leadership. MIS Quarterly Executive, 15(2), 141-166.

El-Haddadeh, R. (2020). Digital innovation dynamics influence on organisational adoption: the case of cloud computing services. Information Systems Frontiers, 22(4), 985-999.

Faems, D., Van Looy, B., \& Debackere, K. (2005). Interorganizational collaboration and innovation: Toward a portfolio approach. Journal of Product Innovation Management, 22(3), 238-250.

Fichman, R. G., Santos, D., B.L., and Zheng, Z. (2014). Digital innovation as a fundamental and powerful concept in the information systems curriculum. MIS Quarterly, 38(2), 329-353.

Flynn, B. B., Sakakibara, S., Schroeder, R. G., Bates, K. A., \& Flynn, E. J. (1990). Empirical research methods in operations management. Journal of Operations Management, 9(2), 250-284.

Foltean, F. S., Trif, S. M., \& Tuleu, D. L. (2019). Customer relationship management capabilities and social media technology use: Consequences on firm performance. Journal of Business Research, 104, 563-575.

Fornell, C., \& Larcker, D. F. (1981). Evaluating structural equation models with unobservable variables and measurement error. Journal of Marketing Research, 18(1), 39-50.

Fuchs, C., \& Sevignani, S. (2013). What is digital labour? What is digital work? What's their difference? and why do these questions matter for understanding social media? TripleC, 11(2), 237-293.

Gobble, M. M. (2018). Digitalization, digitization, and innovation. Research-Technology Management, 61(4), 56-59.

Guszcza, J., Lewis, H., \& Evans-Greenwood, P. (2017). Cognitive collaboration: Why humans and computers think better together. New York,: Deloitte University Press 1 (20): 7-30.

Hair, J. F., Black, W. C., Babin, B. J., Anderson, R. E., \& Tatham, R. L. (1998). Multivariate data analysis (Vol. 5, No. 3, pp. 207-219). Upper Saddle River, NJ: Prentice hall.

Hair, J. F., Sarstedt, M., Ringle, C. M., \& Mena, J. A. (2012). An assessment of the use of partial least squares structural equation modeling in marketing research. Journal of the Academy of Marketing Science, 40(3), 414-433.

Henfridsson, O., \& Yoo, Y. (2014). The liminality of trajectory shifts in institutional entrepreneurship Organization Science. Organization Science, 25(3), 932-950. 
Hoe, S. L. (2017). Thinking about how to think: cognitive skills to stay relevant in a digital economy. Human Resource Management International Digest, 25(5), 1-3.

Hull, C. E., \& Covin, J. G. (2010). Learning capability, technological parity, and innovation mode use. Journal of Product Innovation Management, 27(1), 97-114.

Iansiti, M., \& Lakhani, K. R. (2014). Digital ubiquity: how connections, sensors, and data are revolutionizing business. Harvard Business Review, 92(11), 91-99.

Jahanmir, S. F., \& Cavadas, J. (2018). Factors affecting late adoption of digital innovations. Journal of Business Research, 88, 337-343.

Jarrahi, M. H. (2018). Artificial intelligence and the future of work: Human-AI symbiosis in organizational decision making. Business Horizons, 61, 577-586.

Kache, F., \& Seuring, S. (2017). Challenges and opportunities of digital information at the intersection of Big Data Analytics and supply chain management. International Journal of Operations \& Production Management, 37(1), 10-36

Kallinikos, J., Aaltonen, A., \& Marton, A. (2013). The ambivalent ontology of digital artifacts. MIS Quarterly, 37(2), 357-370.

Kane, G. C., Palmer, D., Phillips, A. N., \& Kiron, D. (2015). Is your business ready for a digital future? Sloan Management Review, 56(4), 37-44.

Kietzmann, J. H., Hermkens, K., McCarthy, I. P., \& Silvestre, B. S. (2011). Social media? Get serious! Understanding the functional building blocks of social media. Business Horizons, 54(3), 241-251.

Kleinbaum, D. G., Kupper, L. L., \& Muller, K. E. (1988). Applied regression analysis and other multivariate methods: student's partial solutions manual. Boston: PWS-Kent Publishing Company.

Kohli, R., \& Melville, N. P. (2019). Digital innovation: A review and synthesis. Information Systems Journal, 29(1), 200-223.

Kolloch, M., \& Dellermann, D. (2018). Digital innovation in the energy industry: The impact of controversies on the evolution of innovation ecosystems. Technological Forecasting and Social Change, 136, 254-264.

Langlois, R. N. (2003). The vanishing hand: the changing dynamics of industrial capitalism. Industrial and Corporate Change, 12(2), 351385.

Lee, J., \& Berente, N. (2012). Digital innovation and the division of innovative labor: Digital controls in the automotive industry. Organization Science, 23(5), 1428-1447.

Legner, C., Eymann, T., Hess, T., Matt, C., Böhmann, T., Drews, P., \& Ahlemann, F. (2017). Digitalization: opportunity and challenge for the business and information systems engineering community. Business \& Information Systems Engineering, 59(4), 301-308.

Lerch, C., \& Gotsch, M. (2015). Digitalized product-service systems in manufacturing firms: A case study analysis. Research-Technology Management, 58(5), 45-52.

Li, L., Su, F., Zhang, W., \& Mao, J. Y. (2018). Digital transformation by SME entrepreneurs: A capability perspective. Information Systems Journal, 28(6), 1129-1157.

Lokuge, S., Sedera, D., Grover, V., \& Dongming, X. (2019). Organizational readiness for digital innovation: Development and empirical calibration of a construct. Information \& Management, $56(3), 445-461$.

Luo, C., Mallick, D. N., \& Schroeder, R. G. (2010). Collaborative product development: Exploring the role of internal coordination capability in supplier involvement. European Journal of Innovation Management, 13(2), 244-266.

Lusch, R. F., \& Nambisan, S. (2015). Service innovation: A servicedominant logic perspective. MIS Quarterly, 39(1), 155-175.

Lyytinen, K., Yoo, Y., \& Boland, R. J. Jr. (2016). Digital product innovation within four classes of innovation networks. Information Systems Journal, 26(1), 47-75.
MacKenzie, S. B., \& Podsakoff, P. M. (2012). Common method bias in marketing: Causes, mechanisms, and procedural remedies. Journal of Retailing, 88(4), 542-555.

Maravilhas, S., \& Martins, J. (2019). Strategic knowledge management a digital environment: Tacit and explicit knowledge in Fab Labs. Journal of Business Research, 94, 353-359.

Marion, T. J., Meyer, M. H., \& Barczak, G. (2015). The influence of digital design and IT on modular product architecture. Journal of Product Innovation Management, 32(1), 98-110.

Merrifield, R., Calhoun, J., \& Stevens, D. (2008). The next revolution in productivity. Harvard Business Review, 86(6), 72-80.

Mikalef, P., Boura, M., Lekakos, G., \& Krogstie, J. (2019). Big data analytics capabilities and innovation: the mediating role of dynamic capabilities and moderating effect of the environment. British Journal of Management, 30(2), 272-298.

Mikalef, P., Pappas, I. O., Krogstie, J., \& Giannakos, M. (2018). Big data analytics capabilities: a systematic literature review and research agenda. Information Systems and e-Business Management, 16(3), 547-578.

Mikalef, P., Pappas, I. O., Krogstie, J., \& Pavlou, P. (2020). Big data and business analytics: A research agenda for realizing business value. Information \& Management, 57(1), 103237.

Mithas, S., Ramasubbu, N., \& Sambamurthy, V. (2011). How information management capability influences firm performance. MIS Quarterly, 35(1), 237-256.

Nambisan, S., Lyytinen, K., Majchrzak, A., \& Song, M. (2017). Digital innovation management: reinventing innovation management research in a digital world. MIS Quarterly, 41(1), 223-238.

Nath, P., Nachiappan, S., \& Ramanathan, R. (2010). The impact of marketing capability, operations capability and diversification strategy on performance: A resource-based view. Industrial Marketing Management, 39(2), 317-329.

Neirotti, P., Raguseo, E., \& Paolucci, E. (2018). How SMEs develop ICT-based capabilities in response to their environment. Journal of Enterprise Information Management. https://doi.org/10.1108/ JEIM-09-2016-0158.

Ngo, L. V., \& O’Cass, A. (2013). Innovation and business success: The mediating role of customer participation. Journal of Business Research, 66(8), 1134-1142.

Nunnally, J. C. (1978). Psychometric theory (2nd ed.). New York: McGraw-Hill.

Nylén, D., \& Holmström, J. (2015). Digital innovation strategy: A framework for diagnosing and improving digital product and service innovation. Business Horizons, 58(1), 57-67.

Pagani, M., \& Pardo, C. (2017). The impact of digital technology on relationships in a business network. Industrial Marketing Management, 67, 185-192.

Pappas, I. O., Mikalef, P., Giannakos, M. N., Krogstie, J., \& Lekakos, G. (2018). Big data and business analytics ecosystems: Paving the way towards digital transformation and sustainable societies. Information Systems and e-Business Management, 16(3), 479-491.

Parida, V., Sjödin, D. R., Lenka, S., \& Wincent, J. (2015). Developing global service innovation capabilities: How global manufacturers address the challenges of market heterogeneity. ResearchTechnology Management, 58(5), 35-44.

Peppard, J., \& Rylander, A. (2006). From value chain to value network: Insights for mobile operators. European Management Journal, 24(2), 128-141.

Porter, M. E., \& Heppelmann, J. E. (2015). How smart, connected products are transforming companies. Harvard Business Review, 93(10), 96-114.

Rachinger, M., Rauter, R., Müller, C., Vorraber, W., \& Schirgi, E. (2019). Digitalization and its influence on business model innovation. Journal of Manufacturing Technology Management, 30(8), 11431160 . 
Richter, A., Heinrich, P., Stocker, A., \& Schwabe, G. (2018). Digital work design - the interplay between human and computer in future work practices as an interdisciplinary (grand) challenge. Journal of Business \& Information Systems Engineering, 60(3), 259-264.

Rogers, E. M. (1983). Diffusion of innovations. New York: A Division of Macmillan Publishing Co.

Santoro, G., Vrontis, D., Thrassou, A., \& Dezi, L. (2018). The internet of things: building a knowledge management system for open innovation and knowledge management capacity. Technological Forecasting and Social Change, 136, 347-354.

Setia, P., Venkatesh, V., \& Joglekar, S. (2013). Leveraging digital technologies: How information quality leads to localized capabilities and customer service performance. MIS Quarterly, 37, 565-590.

Sia, S. K., Soh, C., \& Weill, P. (2016). How DBS Bank pursued a digital business strategy. MIS Quarterly Executive, 15(2), 105-121.

Sivasubramaniam, N., Liebowitz, S. J., \& Lackman, C. L. (2012). Determinants of new product development team performance: A meta-analytic review. Journal of Product Innovation Management, 29(5), 803-820.

Sjödin, D. R., Parida, V., \& Kohtamäki, M. (2016). Capability configurations for advanced service offerings in manufacturing firms: Using fuzzy set qualitative comparative analysis. Journal of Business Research, 69(11), 5330-5335.

Sousa, M. J., \& Rocha, Á (2019). Skills for disruptive digital business. Journal of Business Research, 94, 257-263.

Street, C. T., Gallupe, B., \& Baker, J. (2017). Strategic alignment in SMEs: Strengthening theoretical foundations. Communications of the Association for Information Systems, 40, 20.

Svahn, F., Mathiassen, L., \& Lindgren, R. (2017). Embracing digital innovation in incumbent firms: how Volvo cars managed competing concerns. MIS Quarterly, 41(1), 239-254.
Taber, K. S. (2018). The use of Cronbach's alpha when developing and reporting research instruments in science education. Research in Science Education, 48(6), 1273-1296.

Tanriverdi, H. (2005). Information technology relatedness, knowledge management capability, and performance of multi business firms. MIS Quarterly, 23, 311-334.

Teece, D. J. (2014). The foundations of enterprise performance: Dynamic and ordinary capabilities in an (economic) theory of firms. Academy of Management Perspectives, 28(4), 328-352.

Teece, D. J., Pisano, G., \& Shuen, A. (1997). Dynamic capabilities and strategic management. Strategic Management Journal, 18(7), 509533.

Urueña, A., Hidalgo, A., \& Arenas, ÁE. (2016). Identifying capabilities in innovation projects: Evidences from eHealth. Journal of Business Research, 69(11), 4843-4848.

Westergren, U. H., \& Holmström, J. (2012). Exploring preconditions for open innovation: Value networks in industrial firms. Information and Organization, 22(4), 209-226.

Xue, L. (2014). Governance-knowledge fit and strategic risk taking in supply chain digitization. Decision Support Systems, 62, 54-65.

Yoo, Y. (2010). Computing in everyday life: A call for research on experiential computing. MIS Quarterly, 34, 213-231.

Yoo, Y., Boland Jr, R. J., Lyytinen, K., \& Majchrzak, A. (2012). Organizing for innovation in the digitized world. Organization Science, 23(5), 1398-1408.

Yoo, Y., Henfridsson, O., \& Lyytinen, K. (2010). Research commentary - the new organizing logic of digital innovation: an agenda for information systems research. Information Systems Research, 21(4), 724-735.

Publisher's Note Springer Nature remains neutral with regard to jurisdictional claims in published maps and institutional affiliations. 